\title{
Teachers' Demographic Variables as Predictors of Critical Thinking Skills of School Children: Implications for School Counselling
}

\author{
Felix Okechukwu Ugwuozor ${ }^{1}$, Moses Onyemaechi Ede ${ }^{1}$, Odozi Clara Ifelunni ${ }^{1}$ \& Godwin C. Abiogu ${ }^{1}$ \\ ${ }^{1}$ Department of Educational Foundations, Faculty of Education, University of Nigeria, Nsukka \\ Correspondence: Godwin C. Abiogu, Department of Educational Foundations, Faculty of Education, University of \\ Nigeria, Nsukka. E-mail: godwin.abiogu@unn.edu.ng
}

Received: December 11, 2019 Accepted: April 6, 2020 Online Published: April 30, 2020

doi:10.5539/gjhs.v12n5p91

URL: https://doi.org/10.5539/gjhs.v12n5p91

\begin{abstract}
This study explored the extent to which teachers' demographic variables predict the critical thinking skills of school children, and the educational implications. The study was guided by research questions and null hypotheses, which used a correlation survey design. The population size was 17,928 middle basic pupils in all government-owned schools in Enugu State, Nigeria. Out of the target population, 1,400 pupils were selected using a multistage sampling technique. The instrument used was theCornell Class-Reasoning Test, Form X, which contains 72 items and assessed the respondents' critical thinking skills. The data collected was analyzed using Statistical Packages for Social Sciences (SPSS) version 20. Major findings revealed that teachers' gender does not significantly predict the critical thinking skills of primary-school children in Enugu State, and that teachers' age does not predict critical thinking of primary school children to a large extent. Last, it was found that teachers' location does not predict the critical thinking skills of primary schoolchildren to a large extent. Based on the findings, counseling implications and recommendations are made.
\end{abstract}

Keywords: Teachers' demographics, critical thinking skills, school children, education, Nigeria

\section{Introduction}

Exposure to current knowledge appears to be challenging for everybody, including children. In light of this reality of how knowledge is developed, school children need to be equipped with cognitive ability to analyze tasks in their environment. Evidence abounds that human beings recognize and remember concepts in an environment as the individual grows. As children, they think to achieve sensitivity. Children seem to have natural discretion and the ability to compare and contrast difficult tasks if these skills are well developed (Hyram, 1957; Jensen, 2017; Ku, 2009; Lai, 2011; Potts, 1994; Tarawneh, 2016). In fact, the complexity of environment influences children to think critically when making deductions. To understand the complex nature of human environments requires a high level of critical-thinking skill for mastery (Mercer, 2009; Yusuf \& Adeoye, 2012). The reason for the above assertion is that in as much as new things continued to unfold and develop; children require general problem-solving ability and cognitive skill to be able to cope with contemporary changes in the environment.

Critical thinking (CT) has a rich history in varied field of study (e.g., behavioural sciences and sociology) (Lewis \& Smith, 1993). From the social philosophical approach to CT, Socrates, Plato, Frankfurt, Marx, and Aristotle believed that $\mathrm{CT}$ is based on qualities of deduction which allows children to understand objectivity of knowledge (Lai, 2011; Lewis \& Smith, 1993; Thayer-Bacon, 2000). To date, Matthew Lipman, Jean Piaget, Richard Paul, and Montessori Maria still emphasize the importance of developing children's heads and minds. CT is the process of examining and evaluating the quality of object systematically; applying cognitive skill to make a value judgement of events, finding a new solution to problem situation with concrete evidence (Levy, 1997). CT is also referred to as a pattern of thinking that focused on a particular essential quality with aim of meeting standards of correctness and accurateness (Bailin, 2002; Özden, 2005; Schafersman, 1991) although a limitation in the phenomenon of using different critical thinking skills has been found (Hussain, 2002; Tarawneh, 2016). It, therefore, adduced to be a way of thinking in which you don't simply admit all points of view and conclusions you are exposed to, but rather reason logically and inquire about such conclusions. It is the ability to create ideas through the act of cognitive process. CT involves, task persistence, decision making, critical analysis of task, and ability solve a problem. That is a combination of operational skills and metacognitive ability (Elder \& Paul, 1994). Metacognition means thinking about thinking. It is the knowing of one's higher-order knowledge, that is, children's thoughts to know 
their own understanding of learning situation (Cross \& Paris, 1988; Martinez, 2006).

Furthermore, CT has received significant attention due to its importance in education and students' learning outcomes (Lai, 2011; Özden, 2005; Sternberg, 1986; Tarawneh, 2016). During the teaching and learning process, certain creative cognitive skills are developed that bring about changes in behavior. Children experiment, research, and recognize as well as make sense of the world and their existence. In this respect, this metacognitive operation distinguishes humanity from other species (Arslan, Gulveren, \& Aydin, 2014).

In the school context, some children are apparently inquisitive learners, with a strong desire to be well informed by their teachers (Facione, 1990). They do this under certain ideal conditions their teachers control, instead of being allowed to discover new knowledge by themselves. No wonder that questions pertaining their environment appear to be a source of worry to school children. Previous literature argued that it is the basis of misapprehension to perceive CT as being directly observed; rather, it is the actual process of thought that is observable (Bailin, 2002). In most cases in Nigeria, teachers, parents, and other significant actors seem to view CT as an observable event. Given their views, cognitive counselling psychologists tend to observe children cognitive characteristics.

Teachers are important elements of learning who can promote children's CT skills (Aretz, Bolen, \& Devereux, 1997; Quinn, Burback, Matkin, \& Flores, 2009). The term teacher is the common name used to designate all those (instructors and lecturers) trained to affect knowledge in schools (Ugwu, 2001). In this study, a teacher is treated as a certified person who must have undergone teaching instruction in prerequisite teaching skills and ethical values of teachers.

Quinn et al. (2009) argued that CT of children depend on the pedagogical approach of instructors; content knowledge of $\mathrm{CT}$ and readiness to engage them in innovative learning and experimentation in teaching, and ability to make a classroom environment conducive to $\mathrm{CT}$. This clearly shows that teachers are challenged to foster and encourage children to build up CT skills such as task persistence, reasoning, and task analysis. Educational experts argue that $\mathrm{CT}$ is not occupied with those philosophical and psychological views; rather, it is construed by the taxonomical principle of knowledge, comprehension, analysis, synthesis, and evaluation (Kennedy, Fisher, \& Ennis, 1991). This is not based or built on thoughtful assessment, like the framework developed within either inductive or deductive reasoning or psychology (Sternberg, 1986; Lai, 2011).

Some researchers have claimed that location has a tremendous influence on children's CT skills (e.g. Akabogu, 2006). Children's background knowledge has been described as most essential to the development of CT skills (Case, 2005; Kennedy et al., 1991; Willingham, 2007). It, therefore, implies that location is very critical to the thinking ability of children. Similarly, Bailin (2002) argued that metacognitive enhances CT as it helps to obtain convincing facts across locations. In the context of this study, location refers to the urban and rural residence of the instructors.

Studies have also affirmed that human disposition and age are strong factors with regard to CT, though opinions differ (Facione, 1990). Many scholars agree that an individual's disposition is an important component of CT, but others disagree on the specific function of nature with regards to CT (Lai, 2011). On that note studies argued that human nature or psychological state could play a supportive role while others posited that they also have a normative role (Facione, 1990; Lai, 2011). Lai (2011) emphasizes that being a critical thinker without putting it into practice makes no relevance. It has been lamented that there are manifestations and evidence of CT skills and abilities in students, but many choose not to think critically (Willingham, 2007). Similarly, for CT to transfer spontaneously to new contexts is rare (Lai, 2011; Pithers \& Soden, 2000; Willingham, 2007).

The inability of school children to think critically has generated much concern among counselors, educational policymakers, and researchers. For example, Lai (2011) lamented that some toddlers and adults suffer the inability to think about thinking irrespective of their educational levels. That is, adults, probably including teachers, lack of critical thinking skills, which could imply that teachers may not be able to engage learners actively. However, recent research has found that little children perform the same critical activities that adults do, contending that children in lower elementary grades can think critically (Gelman \& Markman, 1986). Willingham (2007) observed that many children have a tendency to think critically. Given that there is no specific age to say that children are psychologically okay to interpret and solve complicated situation, literature argued thus that since a child continues to grow and develop, he faces complex situations that require critical thinking. In essence, the restricted CT skills of school pupils could be attributed to the absence of related cognitive skills needed to put in place for an academic activity.

Similarly, literature showed that young children in Enugu State, Nigeria, seem to have limited CT skills, which may impair their metacognitive and reasoning skills (Agboeze, Onu, \& Ugwoke, 2013; Federal Republic of 
Nigeria, 2013). It appears that school children in this study area opt for rote learning instead of trying to be critical thinkers due in part to the teaching method (Agboeze, Onu, \& Ugwoke, 2013; Lynch \& Wolcott, 2001; Nwosu, Ebenebe, \& Unachukwu, 2015). For the past two decades, it is the goal of education in Nigeria and curriculum experts, as well as educational researchers, to show more concerns and interest than ever on ways to develop CT skills in students (Adeyemi, 2012; Agboeze, Onu, \& Ugwoke, 2013). For Adeyemi (2012), development of CT skills needs to start at the basic level of education. This implies that inculcation of CT needs to begin with young learners in primary school. To date, many Nigerian schooling children' CT skills are still underdeveloped despite Federal Government of Nigeria efforts to improve teachers' cognitive competence (Yusuf \& Adeoye, 2012). The evidence-supported literature showed that Nigerian teachers are flaws behind why the need to develop CT skills in Nigerian students (Adeyemi, 2012; Thomas \& Nelson, 2010). The inability of schooling children to have higher order thinking skills is apparently attributed to several challenges that could be traceable to teachers, students, pedagogical skills and curriculum content (Adeyemi, 2012; Chukwuyenum, 2013; Osarenren\&Asiedu, 2007; Owolabi, 2003). Teachers' factors include poor consciousness of teachers in rural area; inadequate method of teaching, age, inadequate capacity-building, poor knowledge level of teachersand gender (Abiam \& Odok, 2006; Adeyemi, 2012; Agboeze, Onu, \& Ugwoke, 2013; Bassey, Joshua, \& Asim, 2008; Chukwuyenum, 2013; Ijaiya, Alabi, \& Fasasi, 2010; Nwosu, Ebenebe, \& Unachukwu, 2015). Teacher Education institutes in Nigeria are yet to achieve critical thinking-based curriculum because CT skills are being neglected. Consequently, upon the foregoing, teachers pay little attention to reasoning, induction, deduction, synthesis, and evaluation during classroom instruction (Ijaiya, Alabi, \& Fasasi, 2010). Furthermore, parents have been observed to neglect the effects of their instruction and training. School instructions and home training only introduce students and children to basic knowledge that limits them to performing problem-solving tasks. On that daunting impression, studies have shown that school systems do not consistently produce critical thinkers (Burback, Matkin, \& Fritz, 2004; Paul, 1992). This has been a recent source of worry to both parents and educators.

Typical school instruction could permit children to drive knowledge, interest, experience, ideas, and thought through CT though it may not be the general consensus.In line with this prior study showed that such instructional behaviours permit rote learning which perhaps does not allow young children to explore, synthesize and evaluate events using their abilities (Lai, 2011). As they memorize statements and quotes to pass their examination, they fail to realise the implications. This instruction method makes most pupils de-emphasize consideration of the thinking component of CT and instead believe that rote learning is the best way to acquire knowledge (Paul, 1992).

A good example of this was highlighted by Halpern (1998) that people do not engage in actions that are evidence-based rather they prefer mysterious and magical phenomenon believe to CT. The inability to think may not be linked to poor ways of thinking but to bugs in the analysis of phenomena (Halpern, 1998). Naturally, human beings are meant to follow a specific standard and prototype of how things started and the attributed consequences (Halpern, 1998).

Despite evidence that children struggle to understand the meaning of CT, yet teachers and some experts are still of the opinions that children can learn how to solve difficult situations with appropriate instruction (Lai, 2011). However, the children have exposure to various instructional methods yet they are still lacking the competence needed to persist in hard tasks. This showed the importance of CT related instruction in the educational system and as in the intellectual development of school-based students (Kennedy et al., 1991). Similarly, Lewis and Smith (1993) argued that every child; privileged and less privileged can benefit from CT. Given the importance of CT, educators and instructors are charged to make their instructions to be problem-based for students' patterns of thinking to grow and develop (Mahmoodabad, Nadrian, \& Nahangi, 2012). From foregoing, every child has the innate capacity to deduce knowledge through CT. It, therefore, behooves educators and significant others to try and develop CT skills, especially the inference and deduction domains, in their pupils and children.

With these in mind, it appears that some factors influence the CT skill of children. Previous study found that gender, residency, and age have little influence on CT skills of students in Iran (Mahmoodabad et al., 2012). By implication, CT now is biological although it was contested that gender could be associated with CT (Arslan, et al, 2014). The authors indicated that female counterpart thinks critically compared to male students with regards to CT skills. This explains that the predisposition of female to analyze tasks involves $\mathrm{CT}$ and it could help them judge event with evidence. This supports Arslan et al. finding that the sexual characteristics and CT propensity are significantly related although the association is low. On the other hand, there was a negative low-level correlation between CT tendency and age of the children (Arslan et al., 2014).

In addition, there is a gap in the literature on how significant others influence students' cognitive ability, motivation, and engagement (Steinmayr \& Spinath, 2009). The knowledge gap could be attributed to lack of 
deductive and inductive reasoning, poor content knowledge, and experiences of school teachers and others (Lai, 2011). No wonder, Paul (1992) decried the nature and standard of instruction in educational settings; that they are not CT driven and seems to affect reasoning abilities of school children. On this note, it is uncertain to the authors of this article the extent to which demographic and psychological factors can influence the critical thinking skills of in-school children. It is not clear yet if the school is only one part of a human's education and source of CT ability of children. It is against this background that this study was conceived.

\section{Research Methods}

\subsection{Design of the Study}

A correlational design was used in the study. According to Nworgu (2015), correlation seeks to establish a relationship between two or more variables. In this study, the researchers will attempt to establish the relationship between teacher demographic variables (gender, age, and location) and critical thinking skills of primary school pupils in Nigeria.

\subsection{Area of the Study}

The study was carried out in Enugu North (Obollo-Afor Education Zone) of Enugu State, Nigeria. This study area has three local government areas namely Udenu, Igbo-Eze North, and Igbo-Eze South. In this zone, the inhabitants are predominantly farmers, though some are civil servants and traders. The rationale for chosen the study area is based on the fact that the significant others there seems not to be aware of their impact on the reasoning skill of their children.

\subsection{Population of the Study}

The population size was all the middle basic pupils $(\mathrm{N}=17,928)$ in all 209 public primary schools in Obollo-Afor Education Zone (Enugu State Universal Basic Education Board [ESUBEB], 2015).

\subsection{Sampling Technique}

Researchers selected a sample size of 1,400 , which was $12.8 \%$ of the target population. Multistage sampling was used in this study. First, simple random sampling without a replacement technique was adopted to sample the three local government areas. The intent was to ensure that the subjects are adequately represented. Second, 25 primary schools were sampled from the selected local government areas using a proportionate sampling technique. Then first 56 pupils from each primary school whose parents provided written informed consent were selected as the participants. In addition, these pupils met the other inclusion criteria of the study including not being intellectually disabled and having the ability to respond to quantitative reasoning. Last, from each of the randomly selected schools and local governments, 1,400 participants (Igbo-Eze North: $\mathrm{n}=525$ pupils; Igbo-Eze South: $\mathrm{n}=350$ pupils; and Udenu: $\mathrm{n}=525$ pupils) were sampled using a proportionate sample technique. In each class, 35 pupils were sampled.The sample size selected from each Local government is not consistent because Igbo-Eze South has the smallest number of pupils compare to Igbo-Eze North and Udenu local governments since proportionate sample technique permits selection higher sample size according to population stratum (Ali, 2006; Nworgu, 2015). The sample size calculation was subjected to a priori statistical power of 0.94 using GPower 3.1 software which indicated that the sample size was ok (Faul, Erdfelder, Lang, \& Buchner, 2007).

\subsection{Measures}

The instrument used aCornell Class-Reasoning Test, Form X (CCRTFX), which contains 72 items that helped to assess the respondents' CT skills. The instrument assessed children ability to judge the authenticity of sources of information, quality of assumption, credibility as well as the inductive and deductive meaning of situations. Granted that the instrument test ability to think, the researchers administered the instruments to the respondents individually. The test items were adapted from Ennis, Gardiner, Morrow, Paulus, and Ringel (1964). The adapted version of CCRTFX has two sections A and B. Section A obtained bio-data of the respondents namely name, school, age, location, gender, and class. Section B contains 72 items organized into five subscales. The first subscale based on induction from items 3-25, 48, 50; second subscale tested deduction and assumptions with items 52-65, 67-76; and finally third subscale tested observation and credibility 27-50. The CCRTFX is structured using 3-point Likert-type rating scales (Yes, No and Maybe). The CCRTFX has an internal reliability consistency of 0.87 (see Ennis et al., 1964).

\subsection{Method of Data Analysis}

To collect data for this study, researchers personally distributed 1,400 copies of the instrument to the pupils in their school venues. Prior to the data collection, a written informed consent was obtained from the subjects, headteachers, and parents. The informed consent letter specified privacy issues and potential consequences (Cohen, 
Manion, \& Morrison, 2007; Frankfort-Nachmias \& Nachmias, 1992). The schools that did not respond to informed consent letter by the Headteachers were excluded from the study. Researchers used local vernacular in carrying out the activity, which lasted for 7 months. The instructions and items were read aloud by the researchers soliciting for their responses. During the administration of instrument, that the copies of the instrument were completed in presence of the researchers. This was helpful as it enabled the researchers to clarify uncertainties and increase response rate (Cohen, Manion, \& Morrison, 2007). The researchers ensured a good atmosphere during the administration of the instrument to children. Thereafter, Pearson product-moment correlation coefficient was used to answer the research questions, and multiple-regression statistical tools were used to analyze the data collected from the research questions and to test the postulated null hypotheses (listed in the Results section) at .05 probability levels.

\section{Results}

Table 1. Teachers' Demographic Variables

\begin{tabular}{|c|c|c|c|c|c|}
\hline Variables & No of Teachers & No of Schools & $\begin{array}{c}\text { No of } \\
\text { Pupils } \\
\text { Per Class }\end{array}$ & $\begin{array}{l}\text { No of Class (2 } \\
\text { classes per a } \\
\text { school) }\end{array}$ & $\begin{array}{c}\text { No of Pupils Selected according } \\
\text { to teachers' variables (Per } \\
\text { Teacher) }\end{array}$ \\
\hline \multicolumn{6}{|l|}{ Location } \\
\hline Urban & $20(50 \%)$ & $10(50 \%)$ & 35 & $20(50 \%)$ & $700(50 \%)$ \\
\hline Rural & $20(50 \%)$ & $10(50 \%)$ & 35 & $20(50 \%)$ & $700(50 \%)$ \\
\hline Total & $40(100 \%)$ & $20(100 \%)$ & & $40(100 \%)$ & $1400(100 \%)$ \\
\hline \multicolumn{6}{|l|}{ Age } \\
\hline $25-35$ & $6(15 \%)$ & $3(15 \%)$ & 35 & $6(15 \%)$ & $210(15 \%)$ \\
\hline $36-44$ & $12(30 \%)$ & $6(30 \%)$ & 35 & $12(30 \%)$ & $420(30 \%)$ \\
\hline $45-55$ & $8(20 \%)$ & $4(20 \%)$ & 35 & $8(20 \%)$ & $280(20 \%)$ \\
\hline $56-64$ & $14(35 \%)$ & $7(35 \%)$ & 35 & $14(35 \%)$ & $490(35 \%)$ \\
\hline Total & $40(100 \%)$ & $20(100 \%)$ & & $40(100 \%)$ & $1400(100 \%)$ \\
\hline \multicolumn{6}{|l|}{ Gender } \\
\hline Male & $20(50 \%)$ & $10(50 \%)$ & 35 & $20(50 \%)$ & $700(50 \%)$ \\
\hline Female & $20(50 \%)$ & $10(50 \%)$ & 35 & $20(50 \%)$ & $700(50 \%)$ \\
\hline Total & $40(100 \%)$ & $20(100 \%)$ & & $40(100 \%)$ & $1400(100 \%)$ \\
\hline
\end{tabular}

The pupils were selected based on school teachers' location (urban: $\mathrm{n}=20(50 \%)$ and rural $=20(50 \%)$, number of school per urban: $10(50 \%)$ and rural: $10(50 \%)$; number of class per school: rural $n=20(50 \%), n=20(50 \%)$; age $(25-35: \mathrm{n}=6(15 \%) ; 36-44: \mathrm{n}=12(30 \%) ; 45-55: \mathrm{n}=8(20 \%) ;$ and 56-64: $\mathrm{n}=14(35 \%)$; Number of school per age range 25-35: $\mathrm{n}=3(15 \%) ; 36-44: \mathrm{n}=6(30 \%) ; 45-55: \mathrm{n}=4(20 \%) ; 56-64: \mathrm{n}=7(35 \%)$ and gender (male: $\mathrm{n}=$ $20(50 \%)$ and female: $\mathrm{n}=20(50 \%)$; sample schools based on gender: male $\mathrm{n}=10(50 \%)$; female: $\mathrm{n}=10(50 \%)$; number of class per school based on gender: male: $n=20(50 \%)$; female $n=20(50 \%)$ (see Table 1$)$.

To what extent does teachers' gender predict critical thinking of primary school children?

Table 2. Model Summary of the Extent to Which Teachers' Gender Predicts Critical Thinking of Primary-School Children

\begin{tabular}{lllllll}
\hline \multirow{2}{*}{ Outcome } & $R$ & \multirow{2}{*}{$R^{2}$} & Adjusted $R^{2}$ & Std Error & \multicolumn{2}{c}{ Change Statistics } \\
\cline { 5 - 7 } & & & & $R^{2}$ Change & $F$ Change \\
\hline CCRTFX & .007 & .000 & -.001 & .49591 & .000 & .062 \\
\hline
\end{tabular}

Note. $\alpha=0.05 ; R^{2}=$ coefficient of determination. 
The overall predictive index in Table 2 shows the extent to which teachers' gender predicts CT of primary-school children. The analysis revealed that relationship exists between the teachers' gender (predictor variable) and Critical Thinking (criterion variable) was .007 and the $R^{2}$ was .000 . This indicated that teachers' gender accounts for $0 \%$ of the CT of primary-school children. On the other hand, $0 \%$ of the CT of primary-school children is accounted for by the predictor variable (teachers' gender). By implication, $100 \%$ of the variation in children's CT could be accounted for by other factors. Hence, teachers' gender does not predict CT of primary children to a large extent.

To what extent does teachers' gender not predict critical thinking of primary-school children?

Table 3. Regression Analysis of Teachers' Gender and Critical Thinking of Primary-School Children

\begin{tabular}{lllllll}
\hline Outcome & Model & Sum of Squares & $D f$ & Mean Square & $F$ & Sig. \\
\hline \multirow{3}{*}{ CCRTFX } & Regression & 0.015 & 1 & 0.015 & 0.062 & 0.803 \\
& Residual & 343.807 & 1398 & 0.246 & & \\
& Total & 343.822 & 1399 & & & \\
\hline
\end{tabular}

Note. $\alpha=0.05$.

The result in Table 3 shows that an $F$ value of 0.062 , associated with the probability value of 0.803 , was obtained. This probability value showed that it was not significant. Therefore, the null hypothesis was not rejected. It implies that teachers' gender does not predict CT of primary-school children.

To what extent does teachers' age not predict critical thinking of primary-school children?

Table 4. Model Summary of the Extent to Which Teachers' Age Predicts Critical Thinking of Primary-School Children.

\begin{tabular}{llllllc}
\hline \multirow{2}{*}{ Outcome } & \multirow{2}{*}{$R$} & \multirow{2}{*}{$R^{2}$} & \multirow{2}{*}{ Adjusted $R^{2}$} & \multirow{2}{*}{ Std Error } & \multicolumn{2}{c}{ Change Statistics } \\
\cline { 6 - 7 } & & & & & $R^{2}$ Change & $F$ Change \\
\hline CCRTFX & .008 & .000 & -.001 & .49916 & .000 & .086 \\
\hline
\end{tabular}

Note. $\alpha=0.05 ; R^{2}=$ coefficient of determination.

Table 4 showed the predictive index of the extent to which teachers' age predicts CT of primary-school children. The analysis revealed that relationship that exists between the Teachers' Age and the Critical Thinking was .008 and the $R^{2}$ was .000 . The result indicates that teachers' age accounts for $0 \%$ of CT of primary-school children. On the other hand, $0 \%$ of CT of primary-school children is accounted for by the predictor variable-teachers' gender. By implication, $100 \%$ of the variation in children' $\mathrm{CT}$ is thus accounted for by other factors. Hence, teachers' age does not predict CT of primary children to a large extent.

Teachers' gender does not predict critical thinking of primary-school children.

Table 5. Regression Analysis of Teachers' Age and Critical Thinking of Primary-School Children

\begin{tabular}{lllllll}
\hline Outcome & Model & Sum of Squares & Df & Mean Square & $F$ & Sig. \\
\hline \multirow{3}{*}{ CCRTFX } & Regression & .021 & 1 & .021 & .086 & .769 \\
& Residual & 348.333 & 1398 & .249 & & \\
& Total & 348.354 & 1399 & & & \\
\hline
\end{tabular}

The result in Table 5 shows that an $F$ value of .086 with associated the probability value of .769 was obtained. This probability value indicated that there was no significant relationship between teachers' age and CT. It implies that teachers' age does not predict CT of primary-school children.

To what extent does teachers' location not predict on critical thinking of primary-school children? 
Table 6. Model Summary of the Extent to Which Teachers' Location Predicts Critical Thinking of Primary-School Children

\begin{tabular}{llllllc}
\hline \multirow{2}{*}{ Outcome } & \multirow{2}{*}{$R$} & \multirow{2}{*}{$R^{2}$} & Adjusted $R^{2}$ & Std Error & \multicolumn{2}{c}{ Change Statistics } \\
\cline { 6 - 7 } & & & & & $R^{2}$ Change & $F$ Change \\
\hline CCRTFX & .007 & .000 & -.001 & .49917 & .000 & .069 \\
\hline
\end{tabular}

Note. $\alpha=0.05 ; R^{2}=$ coefficient of determination.

Table 6 showed the overall predictive index of the extent to which teachers' location predicts CT of primary-school children. The analysis revealed that relationship that exists between the Teachers' Location and the Critical Thinking was .007 , and the coefficient determination $\left(R^{2}\right)$ was .000 . This indicates that teachers' location accounts for $0 \% \mathrm{CT}$ of primary-school children. On the other hand, predictor variables for teachers' gender account for $0 \%$ of CT of primary-school children. By implication, $100 \%$ of the variation in children's CT is accounted for by other factors. Hence, teachers' location does not predict CT of primary children to a large extent.

Teachers' location does not predict critical thinking of primary-school children.

Table 7. Regression Analysis of Teachers' Location and Critical Thinking of Primary-School Children

\begin{tabular}{lllllll}
\hline Outcome & Model & Sum of Squares & $D f$ & Mean Square & $F$ & Sig. \\
\hline \multirow{3}{*}{ CCRTFX } & Regression & .017 & 1 & .017 & 0.069 & 0.793 \\
& Residual & 348.337 & 1398 & .249 & & \\
& Total & 348.354 & 1399 & & & \\
\hline
\end{tabular}

The result in Table 7 shows that an $F$ value of 0.069 associated with the probability value of 0.793 was obtained. This probability value indicated that there was no significant relationship between teachers' location and CT of primary-school children. It implies that teachers' location does not predict CT of primary-school children.

\section{Discussion}

This study explored the extent to which teachers' demographic variables predict the critical thinking skills of schoolchildren. This study showed that teachers' gender does not predict CT of school children to a large extent. This result is not in consonance with Arslan et al. (2014), who found that gender can be associated with intent to engage in critical reasoning although the level of relationship could be low. The variation in the prior study and current study could link to the study areas and population. This is noted in the sample of the former study were University students which could account for the difference. Probably, in Usak University the curriculum content, teachers' training, qualifications and pedagogical skills could have influenced the close relationship between the independent and dependent variables. No wonder the Arslan et al highlighted teachers' variables as a limitation and thus require to be reviewed by future research. However, our finding is surprising as most teachers and students in the target country usually attribute intuitive power and problem-solving ability to gender. It could be that the average Nigerian man is gender sensitive. In line with such assertions, prior study noted that many Nigerians are so kin about gender and strongly perceived (Ede, 2014; Odiagbe, 2017; Ohagwu, Eze, Eze, Odo, Abu, \& Ohagwu, 2014; Olaogun, Ayoola, Ogunfowokan, \& Ewere, 2009).This could also be the possible reason why, in most every African Igbo sociocultural setting, the opinion of men always prevails. By contrast, this study showed that gender is not a factor. Our finding also supports the previous study that showed that gender has little influence on children's CT skills (Mahmoodabad et al., 2012). What seems significant in the development of CT are, as Quinn et al. (2009) argued, teachers' method of teaching, thinking, value and assumption in respect to personal thoughts of CT and readiness to engage in testing of methods, and skills to create a classroom environment conducive to $\mathrm{CT}$.

This is contrary among many Nigerian teachers who have not been able to develop and inculcate CT ability in our school children due to poor pedagogical skills, knowledge-based competence and gender (Adeyemi, 2012; Osarenren \& Asiedu, 2007; Thomas \& Nelson, 2010; Yusuf \& Adeoye, 2012). However, it seems that teachers' pedagogy accounts for the underdevelopment of children's critical abilities in Nigeria. On this note, cognitive counselling psychologists are therefore charged to collaborate with relevant administrative schools officials to sensitize both teachers and primary-school children to the need for gender equality. Further, they should 
collaborate with other educators to integrate into the curriculum elements that could foster respect for every gender and gender equality.

Granted that with the high preference of gender sensitivity in developing countries like Nigeria, it means that a teacher being female does not specifically help children to develop problem-solving skills, learn intellectual capacity, make decisions, and improve reasoning skill. These have nothing to do with teachers' gender; rather, pupils could reason critically and creatively to the level that they are striving to look at things systematically and analytically and beyond what the physical eyes can see. Thus, there is no major variation in CT with regard to gender (Bidjerano, 2005). By implication, an individual's capacity to be truth-seeking, open-minded, analytical, and systematic is not determined by gender. Thus, a female teacher can make her students analytical and logical in terms of reasoning just as well as a male teacher.

Researchers also found that teachers' age does not predict CT of primary-school children to a large extent. In line with the corresponding hypothesis, it was showed that the relationship between teachers' age and CT of primary-school children is insignificant. These findings disagreed with those of Facione (1990), that human disposition and age are strong factors with regard to CT, though opinions differ. The result affirmed the finding of Silva (2008) that age is not a significant factor when kids are developmentally prepared to discover new difficult patterns of thinking. In addition, it supported a previous study that found age has little influence on CT skills of children (Mahmoodabad et al., 2012). This indicates that development of reasoning skills, task analysis ability, and problem-solving skills do not depend on either young teachers, older adult teachers, or emerging adult teachers. Hence, the academic performance of children differs regardless of the teachers' age in Nigeria.In line with the above, empirical-based Nigerian literatures showed that age of a teacher is not responsible for schooling children to have higher order thinking skills (Chukwuyenum, 2013; Osarenren \& Asiedu, 2007; Owolabi, 2003). As the teacher' age does not account for CT skills, the implication is that re-training of teachers in Nigeria calls for urgent attention. This could awaken teachers' consciousness towards an adequate method of teaching, and development of CT skills in Nigerian Schools (Abiam \& Odok, 2006; Agboeze, Onu, \& Ugwoke, 2013; Bassey, Joshua, \& Asim, 2008; Chukwuyenum, 2013; Nwosu, Ebenebe, \& Unachukwu, 2015). This implies that curriculum planners and educational policymakers need to revisit Nigerian curriculum content, teaching materials, theoretical foundation and textbooks to ascertain why primary school pupils' CT skills are still underdeveloped.

Results further indicated that teachers' location accounts for $0 \%$ of the CT of primary-school children. Thus, the geographical location of a teacher does not determine CT skills of primary children. No significant relationship between teachers' location and CT of primary-school children was found. This accords with previous study findings that residency of teachers has little influence on CT skills of children (Mahmoodabad et al., 2012), but disagrees with Akabogu (2006), who found that location has a tremendous influence on children's CT skills. This is interesting as CT of the children is not dependent on the predictor variable. This present study showed that location does not account for primary-school children's CT skill. Guidance counselors in Nigerian schools should, therefore, impress upon schoolchildren that residence does not determine students' CT abilities. This implies that both urban and rural teachers, as well as primary-school children from those areas, may both be constructive in their problem-solving abilities. It also implies that both urban and rural teachers could add to the improvement of $\mathrm{CT}$ abilities of children. In addition, the research implication is that more environmental and socio-demographic variables (e.g. teachers' capacity-building, qualification, and pedagogical skills) could be considered in future studies.

\section{Conclusion}

The findings of this study have provided insight into what factors participants attributed as predictors of critical thinking. The sample size of 1,400 was selected to investigate and address the issue raised in the research questions. The finding concluded that teachers' gender does not predict CT of primary children to a large extent in Enugu State, Nigeria. To be sure, some of the teachers are older, more experienced individuals who bring a new set of skills to the academic life of these children. Nonetheless, our results concluded that age of teachers does not predict CT of primary children to a large extent. While a few differences related to pedagogical styles or how schoolchildren develop CT, there is no significant difference between teachers' location and the way, in which children learn or develop CT. Concretely, the result of this investigation showed that teachers' location does not predict CT of primary-school children to a large extent.

Together, the three factors demonstrate some kind of interrelationships among them. There was, however, some bidirectional relationship between pedagogical methods and personal factors. Thus, pedagogical skills and re-training of teachers, as well as students' personal factors, are more likely to produce an additive effect on developing CT in primary-school children. This is a subject for further research. Given that teachers' 
capacity-building programme is required, Nigerian government should then promote the development of critical thinking skills through certain teacher development courses or in-service training.

\subsection{Limitations of the Study}

The sample size appeared to be small which tends to affect the generalizability of the findings. In addition, the use of only one instrument also tends to affect the validity of the study instead of using multiple instruments. The items of the instrument tend not to be satisfactory for administration to groups and attempts to cover both principles of valid and invalid arguments in class and sentence logic, but it was good for our objectives. To that ends, future studies may consider administration of the instrument to groups instead of an individual. An additional limitation in course of the study is that the teachers' demographic characteristics like qualification, in-service training, and method of teaching as well as pedagogical skills were not covered. However, Nigerian researchers may examine these in further research.

\section{Funding}

The authors did not receive any financial support for the study.

\section{Competing Interests Statement}

The authors strongly declared no probable conflicts of interest with regards tothe authorship, finance, and research.

\section{References}

Abiam, P. O., \& Odok, J. K. (2006). Factors in students' performance in different branches of secondary school Mathematics. Journal of Education and Technology, 1(1), 161-168.

Agboeze, M. U., Onu, F. M., \& Ugwoke, E. O. (2013).Enhancement of critical thinking skills of vocational and adult education students for entrepreneurship development in Nigeria. Journal of Education and Practice, 4(17), 116-123.

Akabogu, J. U. (2006). Effect of school location on students' achievement in reading comprehension. International Journal of Educational Research, 1(1), 109-114.

Ali, A. (2006). Conducting Research in Education and the Social Sciences Enugu: Tashiwa Networks.

Aretz, A. J., Bolen, M. T., \& Devereux, K. E. (1997).Critical thinking assessment of college students.Journal of College Reading and Learning, 28(1), 12-23.https://doi.org/10.1080/10790195.1997.10850050

Arslan, R., Gulveren, H., \& Aydin, H. (2014).A research on critical thinking tendencies and factors that affect critical thinking of higher education students. International Journal of Business and Management, 9(5), 43-58. https://doi.org/10.5539/ijbm.v9n5p43

Bailin, S. (2002). Critical thinking and science education. Science \& Education, 11(4), 361- 375. https://doi.org/10.1023/A:1016042608621

Bassey, S. W., Joshua, M. T., \& Asim, A. E. (2008). Gender differences and Mathematics performance of rural senior secondary students in Rivers State, Nigeria.Proceedings of International Conference to Review Research in Science, Technology and Mathematics Education. Munba, India, 2(3), 12-18.

Bidjerano, T. (2005). Gender differences in self-regulated learning. Retrieved from http://eric.ed.gov/?id=ED490777.

Burback, M. E., Matkin, G. S., \& Fritz, S. M. (2004). Teaching critical thinking in an introductory leadership course utilizing active learning strategies: A confirmatory study. College Student Journal, 38(3), 482-493.

Case, R. (2005). Moving critical thinking to the main stage. Education Canada, 45(2), 45- 49.

Chukwuyenum, A. N. (2013). Impact of critical thinking on performance in Mathematics among senior secondary school students in Lagos State. Asuai Nelson IOSR Journal of Research \& Method in Education (IOSR-JRME), 3(5), 18-25. https://doi.org/10.9790/7388-0351825

Cross, D. R., \& Paris, S. G. (1988). Developmental and instructional analyses of children's metacognition and reading comprehension. Journal of Educational Psychology, 80(2), 131-142. https://doi.org/10.1037/0022-0663.80.2.131

Cohen, L., Manion, L., \& Morrison, K. (2007). Research Methods in Education. USA and Canada: Routledge

Elder, L., \& Paul, R. (1994). Critical thinking: Why we must transform our teaching. Journal of Developmental Education, 18, 34-35. 
Ennis, R. H., Gardiner, W. L., Morrow, R., Paulus, D., \& Ringel, L. (1964). Cornell Critical Thinking Test Series THE CORNELL CLASS-REASONING TEST, FORM X. Urbana- Champaign: Illinois Critical Thinking Proiect.

Enugu State Universal Basic Education Board [ESUBEB] 2014/2015. Pupils' population by school and local government areas. Enugu: ESUBEB.

Facione, P. A. (1990). Critical thinking: A statement of expert consensus for purposes of educational assessment and instruction. Millbrae: California Academic Press.

Faul, F., Erdfelder, E., Lang, A. G., \& Buchner, A. (2007). G*Power 3: a flexible statistical power analysis program for the social, behavioral, and biomedical sciences. Behavioural Research Methods, 39, 175-191. https://doi.org/10.3758/BF03193146

Federal Republic of Nigeria. (2004). National policy on education.

Frankfort-Nachmias, C., \& Nachmias, D. (1992). Research Methods in the Social Sciences. London: Edward Arnold.

Fischhoff, B., Crowell, N., \& Kipke, M. (1999). Adolescent decision-making: Implications for prevention programs: Summary of a workshop. Washington, DC: National Academy Press.

Gelman, S. A., \&Markman, E. M. (1986).Categories and induction in young children.Cognition, 23, 183-209.https://doi.org/10.1016/0010-0277(86)90034-X

Halpern, D. (1998). Teaching critical thinking for transfer across domains, dispositions, skills structure training, and metacognitive monitoring. American Psychologist, 53, 449-455. https://doi.org/10.1037/0003-066X.53.4.449

Hussein, T. (2002). Guide thinking skills (1st ed.). Amman: Dar pearls.

Ijaiya, N. Y. S., \& Alabi, A. T. (2011). Teacher education in africa and critical thinking skills: need and strategies. https://doi.org/10.3923/rjbm.2011.26.34

Kennedy, M., Fisher, M. B., \& Ennis, R. H. (1991). Critical thinking: Literature review and needed research. In L. Idol \& B. F. Jones (Eds.), Educational values and cognitive instruction: Implications for reform (pp. 11-40). Hillsdale, NJ: Erlbaum.

Ku, K. Y. (2009). Assessing students' critical thinking performance: Urging for measurements using $\begin{array}{lllll}\text { multi-response format. Thinking Skills and Creativity, 4(2009), } & \text { 70-76. }\end{array}$ https://doi.org/10.1016/j.tsc.2009.02.001

Lai, E. R. (2011, June). Critical thinking: A literature review research report. Retrieved from http://images.pearsonassessments.com/images/tmrs/CriticalT hinkingReviewFINAL.pdf

Levy, D. A. (1997).Tools of critical thinking: Metathoughts for psychology. Boston, MA: Allyn and Bacon.

Lewis, A., \& Smith, D. (1993). Defining higher order thinking.Theory into Practice, 32(3), 131-137. https://doi.org/10.1080/00405849309543588

Lynch, C. L., \& Wolcott, S. K. (2001). Helping your students develop critical thinking skills. Kansas: The IDEA Center.

Mahmoodabad, S. S. M., Nadrian, H., \& Nahangi, H. (2012). Critical thinking ability and its associated factors among preclinical students in Yazd ShaheedSadoughi University of Medical Sciences (Iran). Medical Journal of the Islamic Republic of Iran, 26(2), 50-57.

Martinez, M. E. (2006). What is metacognition? Phi Delta Kappan, 87(9), 696-699. https://doi.org/10.1177/003172170608700916

Mercer, J. (2009). Critical thinking and mastery of child development concepts. Retrieved from http://www.thelizlibrary.org/liz/critical-thinking.html

Nworgu, B. G. (2015). Educational Research: Basic Issues and Methodology (3rd ed). Nsukka: University Trust Publishers.

Nwosu, K. C., Ebenebe, R. C., \& Unachukwu, G. C. (2015). Mediating critical thinking skills among Nigerian students: What instructional practices and classroom learning environment can enhance these skills? Retrieved from https://www.researchgate.net/publication/281821505_ 
Odiagbe, S. (2017). Gender, educational attainment and fertility among the Esan of Nigeria. Nigerian Journal of Educational Research, 7(1), 12-19.

Ohagwu, C. C., Eze, C. U., Eze, J. C., Odo, M. C., Abu, P. O., \& Ohagwu, C. I. (2014). Perception of male gender preference among pregnant Igbo women.Annals of medical and health sciences research, 4(2), 173-178. https://doi.org/10.4103/2141-9248.129027

Olaogun, A., Ayoola, A., Ogunfowokan, A., \& Ewere, V. (2009). Preference for the male child and desired family size in Nigeria. African Journal Midwifery Women's Health, 3, 193-217. https://doi.org/10.12968/ajmw.2009.3.4.44804

Osarenren, N., \& Asiedu, A. S. (2007). Counselling implications on the role of the new mathematics teacher in the teaching and learning mathematics. International Journal of Educational Research.

Owolabi, H. O. (2003). The Challenge of Critical Thinking for Curriculum Development and Evaluation in Nigeria. Ilorin Journal of Educational Curriculum, 22(2), 12-20.

Özden, Y. (2005). Öğrenmeveöğretme (7.Baskı) [learning and teaching (7th Edition)]. Ankara: Pegem A Yayıncilık.

Paul, R. W. (1992). Critical thinking: What, why, and how? New Directions for Community Colleges, 77, 3-24. https://doi.org/10.1002/cc.36819927703

Pithers, R. T., \& Soden, R. (2000). Critical thinking in education: A review. Educational Research, 42(3), 237-249. https://doi.org/10.1080/001318800440579

Potts, B. (1994). Strategies for teaching critical thinking. Practical Assessment, Research and Evaluation, 4(3), $1-4$.

Quinn, C. E., Burbach, M. E., Matkin, G. S., \& Flores, K. L. (2009).Critical thinking for natural resource, agricultural and environmental ethics education. Journal of Natural Resources and Life Sciences Education, 38, 221-227. https://doi.org/10.4195/jnrlse.2009.0028

Schafersman, S. D. (1991). An introduction to critical thinking. Retrieved from http://www.freeinquiry.com/criticalthinking.html

Silva, E. (2008). Measuring skills for the 21st century. Washington, DC: Education Sector. Retrieved from $\mathrm{http} / / /$ educationpolicy.air.org/sites/default/files/public ations/MeasuringSkills.pdf

Sternberg, R. J. (1986). Critical thinking: Its nature, measurement, and improvement. Washington, DC: National Institute of Education. Retrieved from http://files.eric.ed.gov/fulltext/ED272882.pdf

Steinmayr, R., \& Spinath, B. (2009). The importance of motivation as a predictor of school achievement. Learning and Individual Differences, 19, 80-90. https://doi.org/10.1016/j.lindif.2008.05.004

Tarawneh, D. I. (2016). Advanced systematic pattern effect controlling the survey of critical thinking skill in the national study of civic education and tenth grade students in the development of Jordan. European Scientific Journal, 12(8), 1857-7881. https://doi.org/10.19044/esj.2016.v12n8p82

Thayer-Bacon, B. J. (2000). Transforming critical thinking: Thinking constructively. New York, NY: Teachers College Press.

Thomas, F., \& Nelson, L. (2010). About the California critical thinking disposition inventory. Indiana University, Centre for post secondary research.

Ugwu, J. C. (2001). Academic freedom and teacher development in Nigeria.Sustainable educational system and the Nigeria civil rule. A Book of Reading, 1(1), 1-9.

Usman, K. O. (2003). Influence of storage of human resources on the effective instruction of mathematics in secondary schools. The Journal of WCCI Nigeria Chapter Forum, 4(2), 176-184.

Wade, T., \& Sommer, S. (2015). A to Z GIS: An illustrated dictionary of geographic information systems. Redlands, CA: ESRI Press.

Willingham, D. T. (2007, summer). Critical thinking: Why is it so hard to teach? American Educator, 8-19.

Yusuf, F. A., \& Adeoye, E. A. (2012). Developing critical thinking and communication skills in students: Implications for practice in education. African research review, 6(1), 311-324. https://doi.org/10.4314/afrrev.v6i1.26 


\section{Copyrights}

Copyright for this article is retained by the author(s), with first publication rights granted to the journal.

This is an open-access article distributed under the terms and conditions of the Creative Commons Attribution license (http://creativecommons.org/licenses/by/4.0/). 